\title{
Cytotoxicity Effect of the Pericarp Extracts of Garcinia forbesii King on MCF-7 Breast Cancer and HepG2 Liver Cancer Cell Lines
}

\author{
Joharman ${ }^{1,2}$, Hadi Poerwono ${ }^{3}$, Sukardiman ${ }^{4, *}$ \\ ABSTRACT \\ Background: The species from the genus Garcinia has long been used as traditional medicine \\ for cancer treatment. Objective: To analyze the phytochemical contents and assess the \\ cytotoxic effects of pericarp extracts of Garcinia forbesii King against MCF-7 breast cancer \\ cells and HepG2 liver cancer cells. Materials and Methods: The phytochemical contents \\ were analyzed using the thin-layer chromatography and the cytotoxic activity was assessed \\ using the MTT assay method. Results: Phytochemical screening showed the presence \\ of alkaloids, flavonoids, terpenoids and polyphenols. The cytotoxic activities of n-hexane, \\ DCM and ethyl acetate extracts on MCF-7 cells were shown with $I_{50} 103.605 \pm 2.3410 \mu \mathrm{g} /$ \\ $\mathrm{mL}, 397.609 \pm 28.0534 \mu \mathrm{g} / \mathrm{mL}$ and $1,518.301 \pm 68.6379 \mu \mathrm{g} / \mathrm{mL}$ respectively, while the $\mathrm{IC}_{50}$ on \\ HepG2 cells were $79.798 \pm 1.2261 \mu \mathrm{g} / \mathrm{mL}, 83.230 \pm 4.2557 \mu \mathrm{g} / \mathrm{mL}$ and $671.875 \pm 94.3338 \mu \mathrm{g} / \mathrm{mL}$ \\ respectively. Conclusion: The n-hexane, DCM and ethyl acetate extracts from pericarps of $G$. \\ forbesii King have cytotoxic activities against MCF-7 and HepG2 cancer cells, therefore, it has \\ the potential to be developed as an anticancer.
}

Key words: Garcinia forbesii King., Cytotoxic, MCF-7, HepG2, Anticancer.

\section{INTRODUCTION}

According to the World Health Organization data in 2004, the top five cancer occurrences in the world were lung cancer, breast cancer, colon cancer, stomach cancer and liver cancer. The cancer incidence increased from 12.7 million cases in 2008 to 14.1 million cases in 2012 . While the number of deaths from cancer increased from 7.6 million people in 2008 to 8.2 million in 2012. It is estimated that in 2030 the incidence of cancer may reach 26 million people and 17 million of them will die from cancer. In poor and developing countries, deaths from cancer increase faster ${ }^{1}$. In women, breast cancer has the highest percentage of new cases $(43.3 \%)$, and the percentage of death is $12.9 \%{ }^{1}$. In men, liver cancer incidences is on the second highest after lung cancer, with $14.5 \%$ deaths ${ }^{2}$.

Many cancer drugs used today are derived from plants. Some of the results of previous studies found that natural anti-cancer compounds are from flavonoids, alkaloids and terpenoids ${ }^{3}$. Some natural compounds that have been widely used as cancer drugs are Taxol from Taxus brevifolia ${ }^{4}$, and vincristine and vinblastine from Vinca rosea $a^{5}$.

The plants from the genus Garcinia of the Clusiaceae tribe are widespread throughout the tropical and subtropical regions. The species from the genus Garcinia has long been used as traditional medicine in many countries, and contains many chemical compounds with many biological activities, including anticancer activity ${ }^{6,7}$. This species are known to contain many compounds such as flavonoids, benzophenone, lanostane, xanthon and terpenoids, which show anticancer activity. 7 -epiclusianone, which is a benzophenone group is isolated from Garcinia brasiliensis ${ }^{8}$. Wallichinanes A-E, which is a group of lanostanes, is isolated from Garcinia wallichii Choisy ${ }^{9}$, nujiangexathone A, which is a group of xanthones, is isolated from Garcinia nujiangensis ${ }^{3}$.

Preliminary research on anticancer activity has been carried out on several Garcinia species. Many plants from Garcinia genus have cytotoxic effects, For example: the root of Garcinia cowa ${ }^{10}$, the stem bark of Garcinia ovalifolia ${ }^{11}$ and Garcinia cylindrocarpa $a^{12}$, the leaves of Garcinia nijuangensis ${ }^{3}$, the fruits of Garcinia wallichi $i^{9}$, the pericarps of Garcinia mangostana ${ }^{13}$, Garcinia brasiliensis ${ }^{8}$ and Garcinia dulcis ${ }^{7}$. The fruits, flesh and seeds of the Garcinia dulcis are also shown to contain active compounds that are apoptotic to HepG2 liver cell lines ${ }^{7}$. The pericarps of Garcinia mangostana have cytotoxic effect on nasopharyngeal cancer cell lines CNE1, CNE2, SUNE1 and HONE1; lung cancer cell lines A549 and GLC82; MCF-7 breast cancer cell lines; and Bel-74021 ${ }^{14}$ and Hep-G2 liver cancer cell lines ${ }^{15}$.

Garcinia forbesii King is one of the species that is widely spread on the island of Kalimantan (Indonesia) and parts of Malaysia ${ }^{16}$. In Banjar, South Kalimantan, this plant is known by its local name Mundar. The phytochemical isolation of this plant extract has found xanthones, 1,3,7-trihydroxy-2- (3-methylbut2-enyl) -xanthone and forbexanthone compounds ${ }^{17}$. Another study has isolated rubraxanthone, which has antibacterial effect, from the stem bark of this plant ${ }^{18}$

No previous publications of study results regarding anticancer activity of the pericarp of G. forbesii King have been found. Therefore, in this study we assessed the cytotoxic effects of n-hexane, DCM, ethyl acetate,

Cite this article: Joharmam, Poerwono H, Sukardiman. Cytotoxicity Effect of the Pericarp Extracts of Garcinia forbesii King on MCF-7 Breast Cancer and HepG2 Liver Cancer Cell Lines. Pharmacog J. 2021;13(1): 226-9. 
n-butanol and water extracts from the pericarps of G. forbesii King on MCF-7 breast cancer cells and HepG2 liver cancer cells.

\section{MATERIALS AND METHODS}

\section{Collection of plant materials}

The pericarps of G. forbesii King were collected in December 2016 in Banjar, South Kalimantan. This plant was identified by the botanist of the UPT Plant Conservation Center, Purwodadi Botanical Garden, LIPI, East Java.

\section{Extraction}

The pericarps of G. forbesii King were cleaned, dried, and then ground into fine powder. The pericarp powder was extracted by maceration using n-hexane solvent for $1 \times 24$ hours and the filtrate was collected. The maceration was repeated three times. All the filtrate was collected and evaporated with a rotary evaporator to obtain a n-hexane dry extract.

The residue obtained from the rest of maceration with $n$-hexane was dried and macerated again using DCM solvent for $1 \times 24$ hours, and this process was repeated three times. The collected filtrate was evaporated with a rotary evaporator until the DCM extract was obtained. Further, the maceration was carried out in the same manner successively using ethyl acetate, n-butanol, and water solvents. The extracts of n-hexane, DCM, ethyl acetate, n-butanol and water were analyzed for their phytochemical contents, and their cytotoxic activities were assessed against MCF-7 breast cancer cells and HepG2 liver cancer cells.

\section{Thin Layer Chromatography (TLC) analysis ${ }^{19-21}$}

The TLC was performed using Kiesel Gel GF254 as the stationary phase. The concentration of sample was $1 \% \mathrm{w} / \mathrm{v}$.

Flavonoids screening was conducted using the n-butanol:glacial acetic acid:water (4:1:5) as the mobile phase, and the ammonia vapor as the appearance spots.

Polyphenols screening was conducted using the chloroform:ethyl acetate:formic acid $(1: 18: 1)$ as the mobile phase, and $\mathrm{FeCl}_{3}$ as the appearance spots.

Terpenoids screening was conducted using the n-heksana:ethyl acetate (4:1) as the mobile phase, and anisaldehyde sulfuric acid as the appearance spots.

Alkaloids screening was conducted using the chloroform:ethyl acetate $(1: 1)$ as the mobile phase and the Dragendorf reagent as the appearance spots.

\section{Cell culture ${ }^{21}$}

The cancer cells used were MCF-7 cell line and HepG2 cell line obtained from the Parasitology Laboratory, Faculty of Medicine, Public Health and Nursing, Universitas Gadjah Mada. The cells were grown in RPMI media. After the cell condition reached $80 \%$ confluent, the cells were harvested according to the harvest protocol. The cells were suspended in RPMI to a concentration of $5 \times 10^{3}$ cells $/ 100 \mu \mathrm{L}$. The cell suspension was inserted into the wells, each $100 \mu \mathrm{L}$ for each well. Every time the cell suspension was inserted into 12 wells, the cells were resuspended again to ensure homogeneity. The cells were incubated in the incubator overnight to allow for cell recovery after harvesting. The plate containing cells was taken from the incubator, and the media was discarded by turning the plate $180^{\circ} \mathrm{C}$ above the dump. The plate was pressed gently over a tissue paper to drain the remaining liquid. 100 $\mu \mathrm{L}$ PBS was put into all the wells filled with cells, and then the PBS was discarded by turning the plate. The remaining liquid was drained with tissue paper.

\section{Preparation of extracts solutions for cytotoxicity assay $^{22,23}$}

A total of $10 \mathrm{mg}$ of each extract was dissolved in $100 \mu \mathrm{L}$ DMSO, and a stock solution of $1 \times 10^{5} \mathrm{ppm}$ was obtained. From the stock solution, sample solutions were made with a concentration of $500 \mathrm{ppm}, 250 \mathrm{ppm}$, $125 \mathrm{ppm}, 62.5 \mathrm{ppm}, 31.25 \mathrm{ppm}$ and 15,625 ppm using culture media as the diluent.

\section{Cytotoxicity assay ${ }^{21}$}

Each sample concentration was put into a well containing cancer cells, three wells for each concentration (triplo). The plate was incubated in an incubator for 24 hours. After 24 hours the cell media was removed, washed using PBS 1x, and $100 \mu \mathrm{L}$ MTT reagent was added to each well, including media control. Cells were re-incubated for 2-4 hours in an incubator until the formazan was formed. Cell conditions were examined with an inverted microscope. After the formazan has clearly formed, a $10 \%$ SDS stopper in $0.1 \mathrm{~N} \mathrm{HCl}$ was added. The plate was wrapped in aluminum foil and incubated in a dark room temperature overnight. After the incubation, the plates was inserted into the ELISA reader, and the absorbance of each well was analyzed with $\lambda=550-600$ $\mathrm{nm}$. Absorbance vs. concentration graphs were made to illustrate the profile of living cells, and the percentage of living cells and IC50 value were calculated using linear regression.

\section{RESULTS}

\section{Chemical contents of the extracts}

The results of TLC analysis of the extracts are shown in Table 1.

\section{Cytotoxic activity}

The cytotoxic activity of each extract against MCF-7 and HepG2 cancer cells expressed by the IC50 values is as shown in Table 2.

\section{DISCUSSION}

The results of TLC analysis of several extracts of G. forbesii King pericarps showed that the n-hexane extract contained flavonoids and terpenoids which quantities were larger than the other extracts. The contents of flavonoids and terpenoids decreased with increasing polarity of the solvents in the successive in G. forbesii king pericarps. The content of alkaloids was very small in quantity, and it was only detected in n-hexane and DCM extracts, whereas in other extracts there was no detectable alkaloids. Polyphenols were present in relatively

Table 1: The chemical contents of Garcinia forbesii King. Extracts.

\begin{tabular}{ccccc}
\hline Extract & Flavonoids & Polyphenols & Terpenoids & Alkaloids \\
\hline n-hexane & +++ & + & ++ & + \\
DCM & ++ & + & ++ & + \\
Ethyl acetate & ++ & ++ & + & - \\
n-butanol & + & + & + & - \\
Water & + & + & + & - \\
\hline
\end{tabular}

Note: -not detectable, +low intensity, ++medium intensity, +++high intensity

Table 2: Cytotoxic activities of Garcinia forbesii King. Extracts.

\begin{tabular}{ccc}
\hline Extract & $\begin{array}{c}\mathrm{IC}_{50} \text { values on MCF-7 } \\
(\mu \mathrm{g} / \mathrm{mL})\end{array}$ & $\begin{array}{c}\mathrm{IC}_{50} \text { values on HepG2 } \\
(\mu \mathrm{g} / \mathrm{mL})\end{array}$ \\
\hline n-hexane & $103.605 \pm 2.3410$ & $83.230 \pm 4.2557$ \\
DCM & $397.609 \pm 28.0534$ & $79,798 \pm 1.2261$ \\
Ethyl acetate & $1,518.301 \pm 68.6379$ & $671,875 \pm 94.3338$ \\
n-butanol & $\mathrm{NC}$ & $\mathrm{NC}$ \\
Water & $\mathrm{NC}$ & $\mathrm{NC}$ \\
\hline
\end{tabular}

NC: Not Countable 
small amounts in almost all non-polar and polar extracts, except in ethyl acetate extract, where they were detected in slightly more amount.

The results of phytochemical screening from the extracts of G. forbesii King pericarps are in line with the results of previous studies on chemical properties in plants from the same genus. For example, the flesh of G. dulcis contains large amounts of flavonoids in the form of xanthones 7. The bark of G. cylindrocarpa contains xanthones which belong to the flavonoid group ${ }^{12}$. Flavonoids and polyphenols are contained in pericarps of G. Mangostana ${ }^{14,15,24}$. The stem bark of G. cola contains alkaloids, flavonoids and terpenoids ${ }^{25}$. The fruits of G. scomburgkiana contains biflavonoids and flavones ${ }^{26}$. Xanthone flavonoids are contained in the roots of G. ovalifolia ${ }^{11}$. In G. forbesii itself, the bark contains forbexanthone and rubraxanthone $\mathrm{e}^{17,18}$.

In vitro anticancer potential is indicated by $\mathrm{IC}_{50}$ values. Smaller $\mathrm{IC}_{50}$ value indicates that the drug or test material is more potent as an anticancer. In this study, the anticancer potential assessed using the MTT essay method showed that the n-hexane extract $\left(\mathrm{IC}_{50} 103.605 \pm\right.$ $2.3410 \mu \mathrm{g} / \mathrm{mL}$ ) had a higher anticancer potential compared to the DCM extract $\left(\mathrm{IC}_{50} 397.609 \pm 28.0534 \mu \mathrm{g} / \mathrm{mL}\right)$, and the ethyl acetate extract $\left(\mathrm{IC}_{50} 1,518.301 \pm 68.6379 \mu \mathrm{g} / \mathrm{mL}\right.$ ) against MCF-7 breast cancer cells. For HepG2 liver cancer cells, the DCM extract $\left(\mathrm{IC}_{50} 79.798 \pm 1.2261 \mu \mathrm{g} /\right.$ $\mathrm{mL}$ ) showed a higher anticancer potential compared to the n-hexane extract $\left(\mathrm{IC}_{50} 83.230 \pm 4.2557 \mu \mathrm{g} / \mathrm{mL}\right)$, and the ethyl acetate extract $\left(\mathrm{IC}_{50}\right.$ $671.875 \pm 94.3338 \mu \mathrm{g} / \mathrm{mL}$ ). The $\mathrm{n}$-butanol and water extracts did not show any anticancer potential against the two cell lines, as indicated by they very high $\mathrm{IC}_{50}$ values.

The results shown by the n-hexane and DCM extracts indicate that the compounds that actively kill or inhibit the growth of HepG2 liver cancer cells and MCF-7 breast cancer cells may be non-polar and semi-polar compounds, especially flavonoids and terpenoids. This is in line with some of the results of previous studies. Sukandar et al. ${ }^{12}$ found several flavonoid compounds such as cylindroxanthones A-C isolated from G cylindrocarpa which had cytotoxic activity against MCF-7 cancer cells with $\mathrm{IC}_{50}$ of $98.54 \mu \mathrm{M}, 168.53 \mu \mathrm{M}$ and $59.05 \mu \mathrm{M}$, respectively, and against HepG2 cancer cells with $\mathrm{IC}_{50}$ of $10.41 \mu \mathrm{M}, 59.53 \mu \mathrm{M}$, and $37.90 \mu \mathrm{M}$, respectively. Hongthong et al. ${ }^{9}$ found several terpenoid compounds namely wallichinanes A-E isolated from G. wallichii had cytotoxic activity against MCF-7 with $\mathrm{IC}_{50}$ of $6.19 \mu \mathrm{M}$ for wallichinanes D compounds, and $>50 \mu \mathrm{M}$ for other compounds.

\section{CONCLUSION}

The pericarps of G. forbesii King contains flavonoid, polyphenol, terpenoid and alkaloid compounds.

The decreasing order of potential cytotoxic activity against MCF-7 cancer cells is n-hexane, DCM and ethyl acetate extracts, whereas for the cytotoxic activity against HepG2 cancer cells, the decreasing order was DCM, n-hexane, and ethyl acetate extracts. The n-butanol and water extracts did not show potential cytotoxic activity againts the two cells.

Extracts of n-hexane, DCM and ethyl acetate from pericarps of G. forbesii King have cytotoxic activity against MCF-7 and HepG2 cancer cells, therefore it has the potential to be developed as an anticancer.

\section{CONFLICTS OF INTEREST}

The authors declare that they have no conflicts of interest.

\section{ACKNOWLEDGEMENT}

We are thankful to the Indonesian Ministry of Research, Technology and Higher Education, for the financial support for our research. We also thank the analyst of the Parasitology Laboratory, Faculty of Medicine, Public Health and Nursing, Universitas Gadjah Mada, for the assistance in cytotoxicity assay.

\section{REFERENCES}

1. Angorowati, Lindra. Faktor Risiko Kanker Payudara Wanita. KEMAS. 2013;8(2):121-6.

2. Wahyuningsih, MSH. Potensi Pengernbangan Obat Bahan Alam Indonesia untuk Penyakit Kanker. MEDIAFKGAMA. 2010;IX(7):21-7.

3. Zhang $L$, Jiling F, Siyuan $K$, Man W, Zhichao $X$, Baojun Z, Wenwei F, Yuanzhi L Hongsheng T, Hongxi X. Nujiangexathone A, a novel compound from Garcinia nujiangensis, suppresses servical cancer growth by targeting hnRNPK. Cancer Letterrs. 2016;380:447-56.

4. Weaver, B.A. How Taxol/paclitaxel kills cancer cells. Molacular Biology of the Cell, Mol Biol Cell. 2014;25(18):2677-81.

5. Martino E, Casamassima G, Castiglione S, Cellupica E, Pantalone S, Papagn $F$, et al. Vinca alkaloids and analogues as anti-cancer agents: Looking back, peering ahead. Bioorg Med Chem Lett. 2018;28(17):2816-26.

6. Bhaswati C, Raghuram K, Rupjyoti B, Javadi M, Ajaikumar B, Kunnumakara Kasturi K, Jibon K. Anticancer Activity of Garcinia Morella on T-Cell Murine Lymphoma Via Apoptotic Induction. Frontiers in Pharmacology. 2016;7(3):1-13.

7. Bakar, MFA, Nor EA, Monica S, Asmah R. Azizul I. Garcinia dulcis Fruit Extract Induces Cytotoxicity and Apoptosis in HepG2 Liver Cancer Cell Line. BioMed Research International. 2015;Article ID 916902:1-10.

8. Sales L, Julia AP, Kleiton SB, Maria SB, Carlos AS, Luiz GT, et al. Anticancer activity of 7-epiclusianone a benzophenone from Garcinia brasiliensis, in glioblastoma. BMC Complementaary \& Alternative Medicine. 2015;15:393-400.

9. Hongthong $S$, Jatuporn $M$, Phanruethai $P$, Darunee $S$, Palangpon K, Samran $P$ et al. Cytotoxic lanostanes from fruit of Garcinia wallichii Choisy (Guttiferae). Bioorganic \& Medicinal Chemistry Letter. 2016;26:5773-9.

10. Kaennakam S, Pongpun S, Santi T. Kaennacowanols A-C, three new xanthones and their cytotoxixity from the roots Garcinia cowa. Fitoterapia. 2015;102:171-6.

11. Pieme CA, Pathaleon A, Emmanuel $Y$, Ajit KS. Epigarcinol and isogarcinol isolated from the root of Garcinia ovalifolia induce apoptosis of human promyelocytic leukemia (HL-60 cells). BMC Res Notes. 2015;8:700-9.

12. Sukandar ER, Taslim E, Sri F, Pongpun S, Thammarat A, SantiT. Cylindroxanthones $\mathrm{A}-\mathrm{C}$, three new xanthones and their cytotoxicity from the stem bark of Garcinia cylindrocarpa. Fitoterapia. 2016;108:62-5.

13. Chaverri JP, Noemi CR, Marisol Ol, Jasmin MPR. Medical properties of mangosteen (Garcinia mangostana). Food and Chemical Toxicology. 2008;46:3227-39.

14. Xu L, Lao Y, Zhao Y, Qin J, Fu W, Zhang Y, Xu H. Screening Active Compounds from Garcinia Species Native to China Reveals Novel Compounds Targeting the STAT/JAK Signaling Pathway. BioMed Research International. 2015;Article ID 910453:

15. Chang $\mathrm{HF}$, Chih-Hsiung Wu, Ling-ling $\mathrm{Y}$. Antitumor and radical scavenging effect of $\boldsymbol{r}$-Mangostin isolated from Garcinia mangostana pericarps against hepatocellular carcinoma cell. Journal of pharmacy and pharmacology 2013;65:1419-28.

16. Lim TK. Edible Medicinal and Non-Medicinal Plants: volume 2, fruits. Springer science Business Media BV. 2012;2:41-3.

17. Harrison LJ, Lup-San L, Guat-Lee S, Keng-Yeow S, Hugh T-W. Xanthones From Garcinia Forbesii. Phytochemistry.1993;33(3):727-8.

18. AlenY, Novi S, Dachriyanus A, Munaf A, NH Ladjis, MV Sargent, Rubraxhantonen dari Garcinia forbesii King. dan Bioaktivitasnya. ResearchGate. 2008;1(2):192201.

19. Sherma J and Bernard F. Handbook of Thin Layer Chromatography, Third edition, Revised and Expanded. Marcel Dekker Inc. New York. 2013;89:271-310.

20. Tiwari P, Bimlesh K, Mandeep K, Gurpreet K, Harleen K. Phytochemical screening and Extraction: A Review. Internationale Pharmaceutica Sciencia. 2011;1(1):98-106

21. Mishra C, Indra T. Phytochemical Screening of Some Medicinal Plants of Chitrakoot Region. Indian Journal of Applied Research. 2015;5:56-60.

22. Septisetyani EP. Protokol in Vitro. Cancer Chemoprevention Research Center (CCRC). Fakultas Farmasi Universitas Gadjah Mada. 2008;1-23.

23. Senthilraja P, Kathiresan K. In vitro cytotoxicity MTT assay in Vero, HepG2 and MCF -7 cell lines study of Marine Yeast. Journal of Applied Pharmaceutical Science. 2015;5(03):080-4

24. Li G, Stacey T, Jeremy JJ. Polyphenols from the mangosteen (Garcinia mangostana) fruit for breast and prostate cancer. Frontiers in Pharmacology. 2013;80(4):1-4.

25. Popoola TD, Olufunsho A, Adeola O, Nkechinyerem O, Chioma U, Amos AF Three indigenous plants used in anti-cancer remedies, Garcinia cola Heckel (stem bark), Uvaria chamae P.Beauv. (root) and Olax subscorpioidea Oliv. (root) show analgesic and anti-inflammatory activities in animal models. Journal of Ethnopharmacology. 2016;194:440-9.

26. Le DH, Katsumi N, Yukiko T, Yoshiyuki M, Takao T. Polyprenylated Benzoylphloroglucinols with DNA Polymerase Inhibitory Activity from the Fruits Garcinia schomburgkiana. Journal of Natural Products. 2016;79:1798-807. 


\section{GRAPHICAL ABSTRACT}

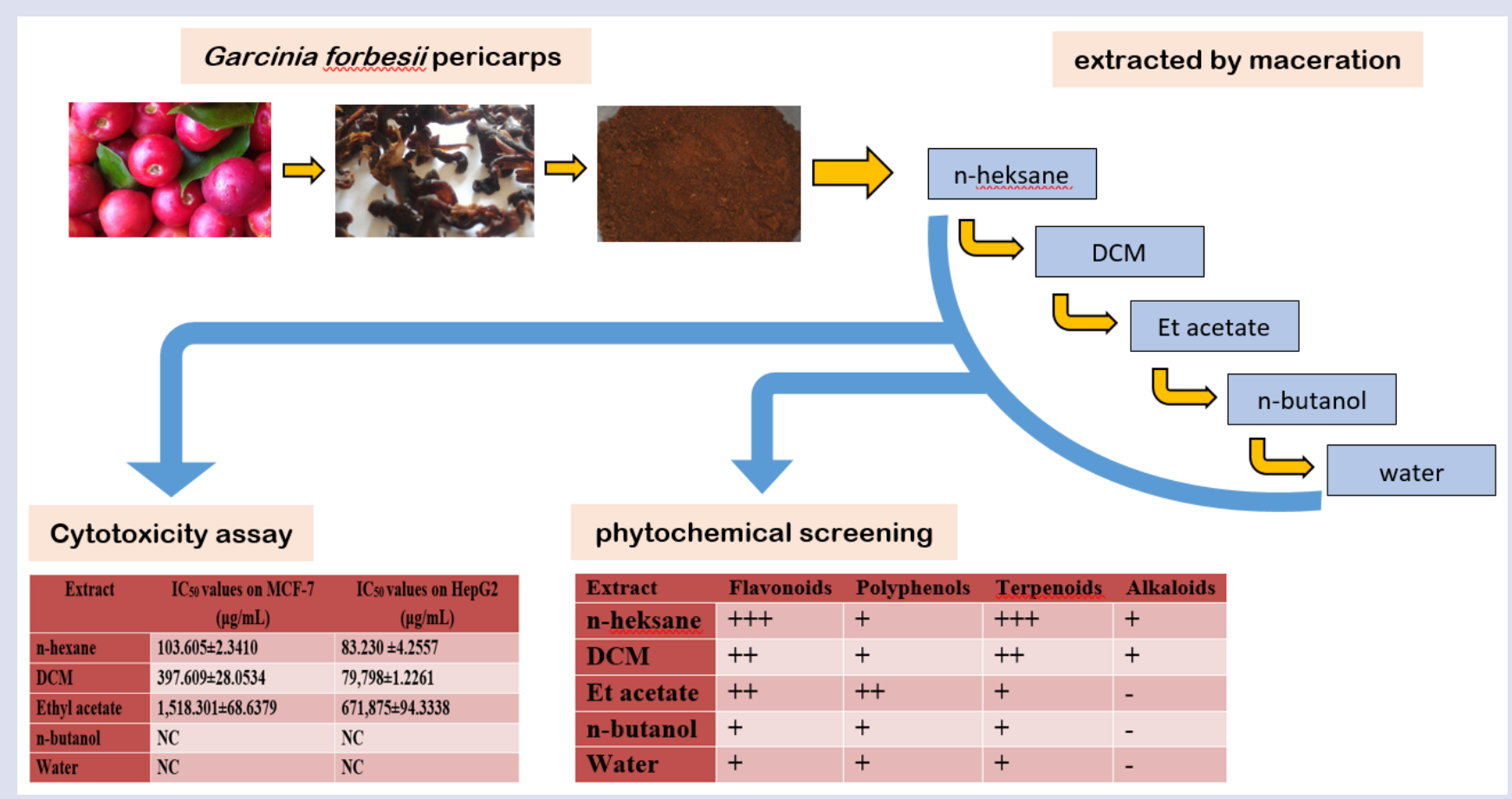

\section{ABOUT AUTHORS}

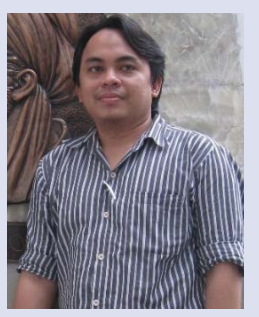

Joharman is a student of doctorate program of Pharmacy at Faculty of Pharmacy, Airlangga University, Surabaya, Indonesia. He is also a lecturer at Department of Pharmacology, Faculty of Medicine, Lambung Mangkurat University, Banjarmasin, Indonesia. He has research experience in the area of pharmacognosy, natural product and pharmacology.

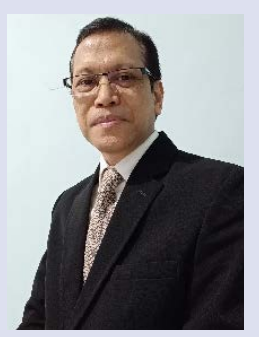

Dr. Hadi Poerwono completed his master course and doctoral course in Graduate School of Pharmaceutical Sciences of Hoshi University, Tokyo, Japan. After receiving his Ph.D. degree in 1999, he is appointed as lecturer in Faculty of Pharmacy, Universitas Airlangga. He gives lectures in Organic Chemistry and Synthetic Chemistry. He also becomes thesis adviser for undergraduate, master course, and doctor course students. His research interest is creating structure modification of active compounds isolated from natural resources for the purpose of improving their potencies as anticancer, antimalaria, antidiabetic, antioxidant and so on. He published numerous articles in various scientific journals.

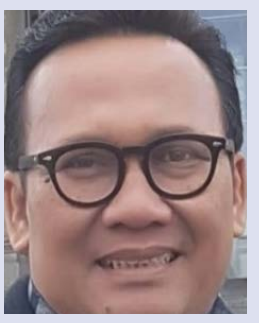

Sukardiman is Professor Pharmacognosy on Department of Pharmacognosy and Phytochemistry, Faculty of Pharmacy, Universitas Airlangga, Surabaya, Indonesia. He has vast experience in the area of pharmacognosy, natural product and pharmacology. He has projects in developing product antidiabetic, anticancer from Indonesian herbal medicine, and herbal standardization. Guiding students for PhD andstudies of various Universities. He has publication in National and International Journal.

Cite this article: Joharmam, Poerwono H, Sukardiman. Cytotoxicity Effect of the Pericarp Extracts of Garcinia forbesii King on MCF-7 Breast Cancer and HepG2 Liver Cancer Cell Lines. Pharmacog J. 2021;13(1): 226-9. 